\title{
Discovery of BMS-753426: A Potent Orally Bioavailable Antagonist of CC Chemokine Receptor 2
}

Michael G. Yang,* Zili Xiao, Rulin Zhao, Andrew J. Tebben, Bei Wang, Robert J. Cherney, Douglas G. Batt, Gregory D. Brown, Mary Ellen Cvijic, John V. Duncia, Michael A. Gallela, Daniel S. Gardner, Purnima Khandelwal, Mary F. Malley, Jian Pang, Anne V. Rose, Joseph B. Santella, III, Amy A. Sarjeant, Songmei Xu, Arvind Mathur, Sandhya Mandlekar, Ragini Vuppugalla, Qihong Zhao, and Percy H. Carter*

Research and Development, Bristol Myers Squibb Company, Princeton, New Jersey 08543-4000, United States

Corresponding Authors

*Michael G. Yang: Phone, 609-252-3234; Email: michael.yang@,bms.com

*Percy H. Carter: Phone, 617-844-8249; Email:

pcarter@blueprintmedicines.com

\section{Chemistry Experimental Procedures}

Characterizations of antagonists 1-6 (Table S1)

page 1

Experimental HPLC methods

Key intermediates 7, 9, and 11-16 (Figure S1)

page 2-3

Synthesis of compounds 1-6 (Table S1)

HPLC analysis of $\mathbf{9 b}$ (Figure S2)

Conformational-Switching Mechanism-based aqueous workup (Figure S3)

Crystal data and structure refinement for 2d (Table S2)

page 3

page 3-11

page 7

page 7

page 11-12

\section{Biology Experimental References}

page 11

Table S1. Characterizations of antagonists 1-6 ${ }^{a}$

\begin{tabular}{|c|c|c|c|c|}
\hline $\begin{array}{l}\text { 1a: } \mathrm{R}=i \text {-Pr } \\
\text { 1b: } \mathrm{R}=\mathrm{Me}\end{array}$ & $\begin{array}{ll}\text { 2a: } \mathrm{R}=i-\operatorname{Pr} & \text { 2c: } \mathrm{R}=\mathrm{H} \\
\text { 2b: } \mathrm{R}=\mathrm{Me} & \text { 2d: } \mathrm{R}=t-\mathrm{Bu}\end{array}$ & 3 & & 6 \\
\hline Compound & $\begin{array}{l}\text { CCR2 Binding } \\
\mathrm{IC}_{50}, \mathrm{nM}\end{array}$ & $\begin{array}{l}\text { MDS-Na }{ }^{+} \\
\text {\%inhibition }\end{array}$ & $\begin{array}{l}\text { Pampa PC } \\
\mathrm{nm} / \mathrm{sec}\end{array}$ & $\begin{array}{l}\text { Metabolic Stability } \\
\% \text { rem }(\mathrm{h} / \mathrm{r} / \mathrm{m} / \mathrm{c})^{d}\end{array}$ \\
\hline $1 \mathrm{a}$ & 1.1 & 21 & 443 & $97 / 95 / 96 / 84$ \\
\hline $1 b$ & 3.9 & 19 & 557 & $100 / 100 / 100 / 93$ \\
\hline $2 a$ & 15 & 22 & 208 & $94 / 100 / 100 / 100$ \\
\hline $2 \mathbf{b}$ & 4.6 & 26 & 235 & $99 / 98 / 98 / 100$ \\
\hline $2 c$ & 2.9 & 35 & 30 & $96 / 100 / 100 / 100$ \\
\hline $2 d$ & 2.7 & 29 & 560 & $100 / 100 / 98 / 94$ \\
\hline 3 & 7.6 & 26 & 507 & 100/99/100/ND \\
\hline 4 & 15 & $\mathrm{ND}^{e}$ & ND & ND \\
\hline $5 \mathbf{a}$ & 3.0 & 20 & 30 & ND \\
\hline $5 \mathbf{b}$ & 1.3 & 52 & 332 & $100 / 99 / 100 / 94$ \\
\hline 6 & 6.6 & 8 & 251 & $100 / 100 / 100 / 83$ \\
\hline
\end{tabular}

${ }^{a} \mathrm{IC}_{50}$ values reported as the average of two or more determinations, except for compound 4. ${ }^{b}$ Inhibition at $30 \mu \mathrm{M}$ concentration. ${ }^{d}$ Metabolic stability is defined as the percentage of parent compound remaining over $10 \mathrm{~min}$ of incubation time in the presence of human, rat and mouse liver microsomes, respectively. The initial compound concentration was $0.5 \mu \mathrm{M}$; protein concentration $1 \mathrm{mg} / \mathrm{mL}$. ${ }^{\text {Not }}$ determined. 


\section{EXPERIMENTAL SECTION}

Chemistry. All commercially available chemicals and solvents were used without further purification. Reactions are performed under an atmosphere of nitrogen. All new compounds gave satisfactory ${ }^{1} \mathrm{H}$ NMR, LC/MS and/or HRMS, and mass spectrometry results. ${ }^{1} \mathrm{H}$ NMR spectra were obtained on a Bruker $400 \mathrm{MHz}$ or a Jeol $500 \mathrm{MHz}$ NMR spectrometer using residual signal of deuterated NMR solvent as internal reference. Electrospray ionization (ESI) mass spectra were obtained on a Water Micromass ESI-MS single quadrupole mass spectrometer. The purity of tested compounds determined by analytical HPLC was $>95 \%$ except as noted. All the analytical and HPLC conditions are described as Method A: PHENOMONEX LUNA C18 S3 4.6 X 150 MM; Mobile Phase: (A) 10\% MeOH / 90\% water; (B) 10\% water / 90\% MeOH; Buffer: $0.2 \%$ $\mathrm{H}_{3} \mathrm{PO}_{4}$; Gradient Range: 0-100\% B; Gradient Time: $15 \mathrm{~min}$; Flow Rate: $1 \mathrm{~mL} / \mathrm{min}$; Analysis Time: $2.0 \mathrm{~min}$; Detection: Detector 1: UV at $220 \mathrm{~nm}$; Detector 2: MS (ES+). Method B: Xbridge Phenyl C18, 3.5- $\mu \mathrm{m}$ particles $(3.0 \times 150 \mathrm{~mm})$; Mobile Phase $\mathrm{A}=0.05 \%$ TFA in $\mathrm{CH}_{3} \mathrm{CN}$ :Water (10:90), Mobile Phase $\mathrm{B}=0.1 \%$ TFA in $\mathrm{CH}_{3} \mathrm{CN}$ :Water (90:10); 10-100\% B gradient over $12 \mathrm{~min}$, then a 3-minute hold at 100\% B. Flow Rate $=1.0 \mathrm{ml} / \mathrm{min} ;$ UV detection $=254 \mathrm{nM}$. Method C: Sunfire C18 4.6 x $150 \mathrm{~mm}$; Mobile Phase A =0.05\% TFA in $\mathrm{CH}_{3} \mathrm{CN}$ :Water (10:90), Mobile Phase $\mathrm{B}=0.1 \%$ TFA in $\mathrm{CH}_{3} \mathrm{CN}$ :Water (90:10); 10-100\% B gradient over $12 \mathrm{~min}$. Flow Rate $=1.0 \mathrm{~mL} / \mathrm{min}$; UV detection $=254 \mathrm{nM}$. Method D: Phenomenex 5u C18 4.6 X 50 MM; Mobile Phase: (A) 10\% MeOH / 90\% water; (B) 10\% water / 90\% MeOH; Buffer: 0.1\% TFA; Gradient Range: 0-100\% B; Gradient Time: 4 min; Flow Rate: $4 \mathrm{~mL} / \mathrm{min}$; Detection: Detector 1: UV at $220 \mathrm{~nm}$; Detector 2: MS (ES+). Method E: PHENOMONEX LUNA 5u 4.6 X 250 MM; Mobile Phase: (A) 10\% $\mathrm{MeOH} / 90 \%$ water; (B) 10\% water / 90\% $\mathrm{MeOH}$; Buffer: $0.2 \% \mathrm{H}_{3} \mathrm{PO}_{4}$; Gradient Range: 0-100\% B; Gradient Time: 8 min; Flow Rate: 1.5 mL/min; UV detection = 220 nM. Method F: YMC ODS-A 4.6 X 50 MM; Mobile Phase: (A) 10\% MeOH / 90\% water; (B) 10\% water / 90\% $\mathrm{MeOH}$; Buffer: 0.2\% $\mathrm{H}_{3} \mathrm{PO}_{4}$;

Gradient Range: 0-100\% B; Gradient Time: 4 min; Flow Rate: $2.5 \mathrm{~mL} / \mathrm{min}$; UV detection $=220 \mathrm{nM}$. Method F: Sunfire S5 4.6 X 30 MM; Mobile Phase: (A) 10\% MeOH / 90\% water; (B) 10\% water / 90\% 
MeOH; Buffer: 0.1\% TFA; Gradient Range: 0-100\% B; Gradient Time: 2 min; Flow Rate: $5 \mathrm{~mL} / \mathrm{min}$; Detection: Detector 1: UV at $220 \mathrm{~nm}$; Detector 2: MS (ES+).

The key intermediates used in this manuscript and their related references are shown in Figure S1. The related synthetic experimental procedures and analytical data can be found in the reported publications.

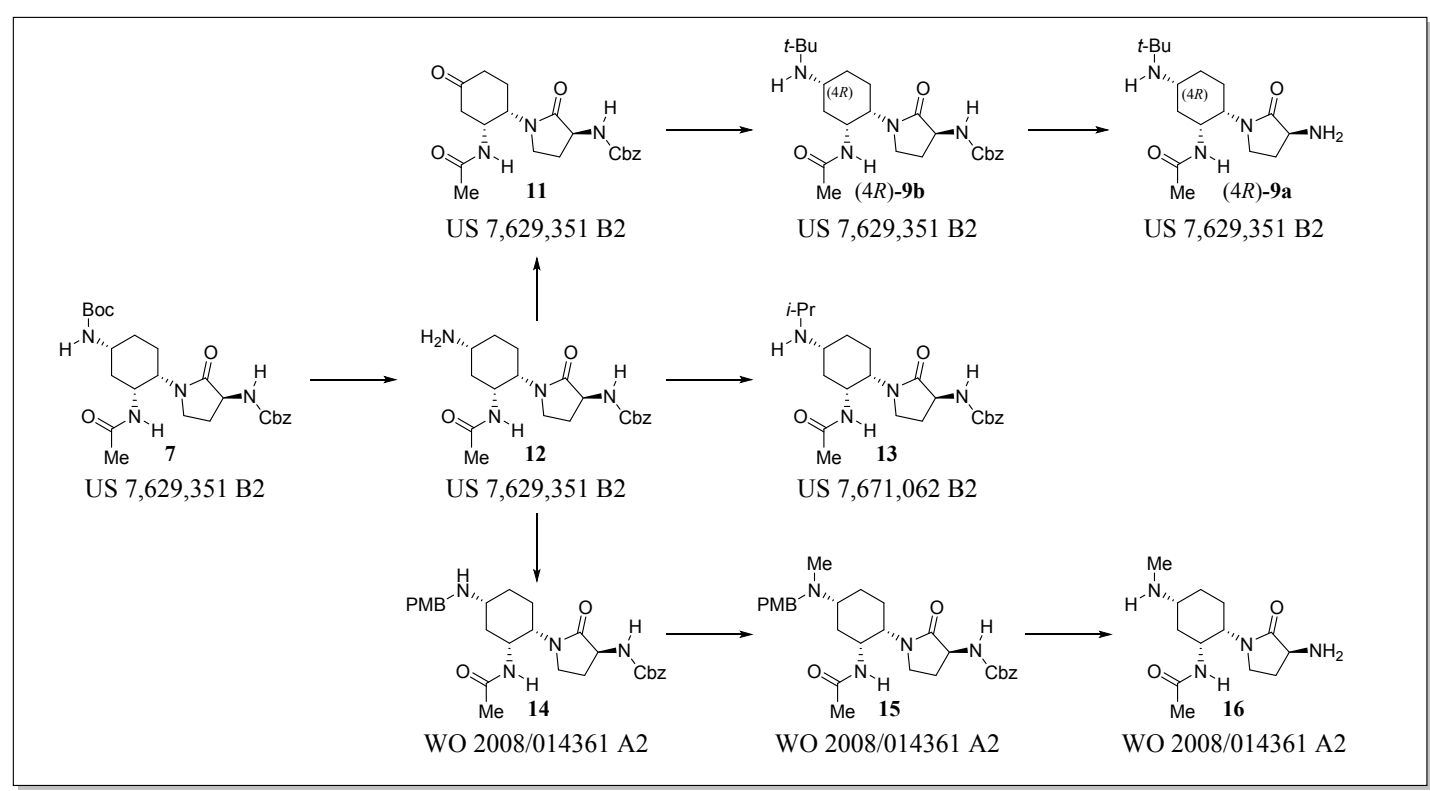

Figure S1. Key intermediates 7, 9, and 11-16.

\section{Synthesis of N-((1R,2S,5R)-5-(dimethylamino)-2-((S)-2-oxo-3-((6-(trifluoromethyl)quinazolin-4-}

yl)amino)pyrrolidin-1-yl)cyclohexyl)acetamide (1b, Table S1). To a solution of 2c (446 mg, 0.99 mmol) in $\mathrm{CH}_{2} \mathrm{Cl}_{2}(20 \mathrm{~mL})$ was added sequentially formaldehyde $(5 \mathrm{~mL}, 37 \mathrm{wt} \%$ solution $)$, triethylamine $(0.35 \mathrm{~mL}$, $2.4 \mathrm{mmol}$ ), and sodium triacetoxyborohydride $(315 \mathrm{mg}, 1.5 \mathrm{mmol})$. After $16 \mathrm{~h}$, the solution was diluted with $\mathrm{CH}_{2} \mathrm{Cl}_{2}$ and washed with saturated $\mathrm{NaHCO}_{3}$. The organic layer was collected and extracted with aq. $\mathrm{HCl}$ solution $(5 \mathrm{~mL}$ in $\mathrm{HCl}$ and $20 \mathrm{~mL}$ water). The aqueous phase was collected and basified with aq. $\mathrm{NaOH}$ solution $(\sim 10 \mathrm{~mL}$ in $\mathrm{NaOH}$ and $20 \mathrm{~mL}$ water $)$ and then extracted with dichloromethane $(2 \times 50 \mathrm{~mL})$. The organic extracts were combined, dried $\left(\mathrm{Na}_{2} \mathrm{SO}_{4}\right)$, filtered, and concentrated in vacuo to give the title compound $\mathbf{1 b}$ (70 mg, 71\% yield). ${ }^{1} \mathrm{H}-\mathrm{NMR}\left(400 \mathrm{MHz}, \mathrm{CD}_{3} \mathrm{OD}\right), \delta$ ppm: $8.87(\mathrm{~s}, 1 \mathrm{H}), 8.72(\mathrm{~s}, 1 \mathrm{H}), 8.22$ (m, 1H), $7.87(\mathrm{~m}, 1 \mathrm{H}), 5.49(\mathrm{~m}, 1 \mathrm{H}), 4.23(\mathrm{~m}, 1 \mathrm{H}), 4.2(\mathrm{~m}, 1 \mathrm{H}), 4.12(\mathrm{~m}, 1 \mathrm{H}), 3.75(\mathrm{~m}, 1 \mathrm{H}), 3.65(\mathrm{~m}, 1 \mathrm{H})$, $3.38(\mathrm{~m}, 1 \mathrm{H}), 2.82(\mathrm{~s}, 6 \mathrm{H}), 2.51(\mathrm{~m}, 1 \mathrm{H}), 2.35(\mathrm{~m}, 1 \mathrm{H}), 2.15(\mathrm{~m}, 1 \mathrm{H}), 2.14-1.86(\mathrm{~m}, 5 \mathrm{H}), 1.84(\mathrm{~s}, 3 \mathrm{H})$. LCMS calculated for $\mathrm{C}_{23} \mathrm{H}_{30} \mathrm{~F}_{3} \mathrm{~N}_{6} \mathrm{O}_{2}[\mathrm{M}+\mathrm{H}]^{+}: \mathrm{m} / \mathrm{z}=479.23$; found: 479. HPLC: $t_{\mathrm{R}}=1.48$ min (Method D). 


\section{Synthesis of N-((1R,2S,5R)-5-(isopropylamino)-2-((S)-2-0xo-3-((6-(trifluoromethyl)quinazolin-4-}

yl)amino)pyrrolidin-1-yl)cyclohexyl)acetamide (2a, Table S1). To a solution of $\mathbf{1 3}$ (30 mg, $0.07 \mathrm{mmol})$ in methanol $(3 \mathrm{~mL})$ was added $10 \% \mathrm{Pd} / \mathrm{C}(30 \mathrm{mg}$ of $50 \%$ wet catalyst). The flask was evacuated and backfilled with hydrogen from a hydrogen balloon. The mixture was stirred at room temperature for $1.5 \mathrm{~h}$ under $1 \mathrm{~atm}$ hydrogen and then the catalyst was removed by filtration. The filtrate was concentrated in vacuo. The residue was dissolved in isopropanol $(3 \mathrm{~mL})$ and charged sequentially with 4-chloro-6(trifluoromethyl)quinazoline (19.4 mg, $1.2 \mathrm{eq})$ and diisopropylethylamine (18 mg, $2 \mathrm{eq})$. The mixture was stirred at room temperature for $1 \mathrm{~h}$. The solvent was removed under reduced pressure. The residue was purified by preparative reverse phase HPLC to provide the title compound 2a as its TFA salt (47 mg, 93\% yield). ${ }^{1} \mathrm{HNMR}\left(400 \mathrm{MHz}, \mathrm{CD}_{3} \mathrm{OD}\right), \delta \mathrm{ppm}: 8.90(\mathrm{~s}, 1 \mathrm{H}), 8.81(\mathrm{~s}, 1 \mathrm{H}), 8.25-8.29(\mathrm{~m}, 1 \mathrm{H}), 7.96(\mathrm{~d}, J=8.65$ Hz, 1H), $5.44(\mathrm{t}, J=9.92 \mathrm{~Hz}, 1 \mathrm{H}), 4.42(\mathrm{~d}, J=2.54 \mathrm{~Hz}, 1 \mathrm{H}), 4.15-4.24(\mathrm{~m}, 1 \mathrm{H}), 3.90(\mathrm{t}, J=8.65 \mathrm{~Hz}, 1 \mathrm{H})$, 3.70-3.79 (m, 1H), 3.46-3.62 (m, 2H), 2.56-2.67 (m, 1H), 2.33-2.47 (m, 1H), 1.70-2.23 (m, 9H), $1.35(\mathrm{~d}, J$ $=6.10 \mathrm{~Hz}, 6 \mathrm{H}) . \quad$ LCMS calculated for $\mathrm{C}_{24} \mathrm{H}_{32} \mathrm{~F}_{3} \mathrm{~N}_{6} \mathrm{O}_{2}[\mathrm{M}+\mathrm{H}]^{+}: \mathrm{m} / \mathrm{z}=493.25$; found: 493.

\section{Synthesis of N-((1R,2S,5R)-5-(methylamino)-2-((S)-2-oxo-3-((6-(trifluoromethyl)quinazolin-4-} yl)amino)pyrrolidin-1-yl)cyclohexyl)acetamide (2b, Table S1). To a solution of $\mathbf{1 6}$ (12.5 g, $46.6 \mathrm{mmol})$ in dichloromethane was added triethylamine $(12.98 \mathrm{~mL}, 93 \mathrm{mmol})$ and 4-chloro-6(trifluoromethyl)quinazoline $(10.83 \mathrm{~g}, 46.6 \mathrm{mmol})$. The mixture was stirred at $\mathrm{rt}$ overnight and then concentrated under reduced pressure to dryness. The residue was dissolved in dichloromethane $(350 \mathrm{~mL})$ and extracted with a solution of aqueous acetic acid $\left(1 \times 200 \mathrm{~mL}, 1\right.$ x $100 \mathrm{~mL}$; made from $300 \mathrm{~mL}$ of $\mathrm{H}_{2} \mathrm{O}$ and $16 \mathrm{~mL}$ of acetic acid. The acidic aqueous layer $(\mathrm{pH} 4-5)$ was extracted with dichloromethane $(2 \times 300$ $\mathrm{mL})$, basified with $\mathrm{Na}_{2} \mathrm{CO}_{4}$ to $\mathrm{pH} 10-11$, and then extracted with dichloromethane $(2 \times 350 \mathrm{~mL}$; maintained $\mathrm{pH}$ of aqueous layer at $10-11$ with $\mathrm{Na}_{2} \mathrm{CO}_{3}$ as necessary). The organic phase was washed with saturated $\mathrm{NaCl}$ solution $(1 \times 200 \mathrm{~mL})$; the $\mathrm{NaCl}$ layer was back-extracted with dichloromethane $(1 \times 100 \mathrm{~mL})$. The organic extracts were combined, dried $\left(\mathrm{Na}_{2} \mathrm{SO}_{4}\right)$, filtered, and concentrated in vacuo to give $\mathbf{2 b}(19.4 \mathrm{~g}, 90 \%)$. ${ }^{1} \mathrm{H}-\mathrm{NMR}\left(500 \mathrm{MHz}, \mathrm{CD}_{3} \mathrm{OD}\right), \delta$ ppm: 8.77 (s, 1H), 8.56 (s, 1H), 8.02 (dd, $\left.J=8.80,1.37 \mathrm{~Hz}, 1 \mathrm{H}\right), 7.87$ (d, $J$ $=8.52 \mathrm{~Hz}, 1 \mathrm{H}), 5.25(\mathrm{t}, J=8.52 \mathrm{~Hz}, 1 \mathrm{H}), 4.53(\mathrm{q}, J=3.94 \mathrm{~Hz}, 1 \mathrm{H}), 4.01(\mathrm{dt}, J=11.96,3.85,3.71 \mathrm{~Hz}, 1 \mathrm{H})$, 
3.46-3.64 (m, 2H), 2.77-2.86 (m, 1H), 2.47-2.57 (m, 1H), $2.41(\mathrm{~s}, 3 \mathrm{H}), 2.22(\mathrm{dq}, J=12.51,12.44,3.57 \mathrm{~Hz}$, $1 \mathrm{H}), 1.98(\mathrm{~s}, 3 \mathrm{H}), 1.95-1.98(\mathrm{~m}, 1 \mathrm{H}), 1.92-1.98(\mathrm{~m}, 1 \mathrm{H}), 1.84-1.91(\mathrm{~m}, 1 \mathrm{H}), 1.78(\mathrm{t}, J=3.44 \mathrm{~Hz}, 1 \mathrm{H}), 1.71-$ $1.76(\mathrm{~m}, 1 \mathrm{H}), 1.62-1.69(\mathrm{~m}, 1 \mathrm{H})$. LCMS calculated for $\mathrm{C}_{22} \mathrm{H}_{28} \mathrm{~F}_{3} \mathrm{~N}_{6} \mathrm{O}_{2}[\mathrm{M}+\mathrm{H}]^{+}: \mathrm{m} / \mathrm{z}=465.21$; found: 465 . HPLC: $t_{\mathrm{R}}=3.61 \min ($ Method F).

\section{Synthesis of $\quad \mathrm{N}-((1 \mathrm{R}, 2 \mathrm{~S}, 5 \mathrm{R})-5-$ amino-2-((S)-2-0xo-3-((6-(trifluoromethyl)quinazolin-4-}

yl)amino)pyrrolidin-1-yl)cyclohexyl)acetamide (2c, Table S1). To a solution of 7 (1.7 g, $3.48 \mathrm{mmol})$ in methanol $(10 \mathrm{~mL})$ was added $10 \% \mathrm{Pd} / \mathrm{C}(0.6 \mathrm{~g}$ of $50 \%$ wet catalyst $)$. The flask was evacuated and backfilled with hydrogen with a hydrogen balloon. The mixture was stirred at $\mathrm{rt}$ under $1 \mathrm{~atm}$ of hydrogen for $14 \mathrm{~h}$ and the catalyst was removed by filtration. The filtrate was concentrated in vacuo to provide tert-butyl ((1R,3R,4S)-3-acetamido-4-((S)-3-amino-2-oxopyrrolidin-1-yl)cyclohexyl)carbamate, LCMS calculated for $\mathrm{C}_{17} \mathrm{H}_{31} \mathrm{~N}_{4} \mathrm{O}_{4}[\mathrm{M}+\mathrm{H}]^{+}: \mathrm{m} / \mathrm{z}=355.23$; found ESI-MS: $m / z$ 355.45 $\left(\left[\mathrm{M}+\mathrm{H}^{+}\right]\right)$, which was taken on to the next step without further purification. This intermediate $(\sim 3.4 \mathrm{mmol})$ was dissolved in isopropanol $(10 \mathrm{~mL})$ followed by 4-chloro-6-(trifluoromethyl)quinazoline (0.97 g, $1.2 \mathrm{eq})$ and diisopropylethylamine (0.88 g, 2 eq). The mixture was stirred at $\mathrm{rt}$ for $2.5 \mathrm{~h}$. The solvent was removed under reduced pressure. The residue was purified with silica gel column chromatography eluting with $1 \%$ and $5 \% \mathrm{MeOH}$ in dichloromethane to provide the crude material of tert-butyl $((1 R, 3 R, 4 S)-3$-acetamido-4- $((S)-2-$ oxo-3- $((6-$ (trifluoromethyl)quinazolin-4-yl)amino)pyrrolidin-1-yl)cyclohexyl)carbamate (1.9 g, 100\% yield). LCMS calculated for $\mathrm{C}_{26} \mathrm{H}_{34} \mathrm{~F}_{3} \mathrm{~N}_{6} \mathrm{O}_{4}[\mathrm{M}+\mathrm{H}]^{+}: \mathrm{m} / \mathrm{z}=551.25$; found ESI-MS: $m / z 551\left(\left[\mathrm{M}+\mathrm{H}^{+}\right]\right)$. A portion of the crude intermediate $(1.65 \mathrm{~g}, 3 \mathrm{mmol})$ was dissolved in dichloromethane $(8 \mathrm{~mL})$ and then charged with trifluoroacetic acid $(4 \mathrm{~mL})$. The reaction was stirred for $1 \mathrm{~h}$ at $\mathrm{rt}$ and concentrated in vacuo. The residue was dissolved in a mixture of $1 \mathrm{~mL}$ of methanol and $5 \mathrm{~mL}$ of dichloromethane. The resulting solution was added dropwise to $80 \mathrm{~mL}$ of $t$-butylmethylether with stirring. The solid formed was collected with filtration and dried to give the title compound $2 \mathrm{c}$ as its TFA salt (1.75 g, 86\% yield). ${ }^{1} \mathrm{H}-\mathrm{NMR}\left(400 \mathrm{MHz}, \mathrm{CD}_{3} \mathrm{OD}\right)$, $\delta$ ppm: $8.82(\mathrm{~s}, 1 \mathrm{H}), 8.77(\mathrm{~s}, 1 \mathrm{H}), 8.20-8.27(\mathrm{~m}, 1 \mathrm{H}), 7.95(\mathrm{~d}, J=8.65 \mathrm{~Hz}, 1 \mathrm{H}), 5.32(\mathrm{t}, J=9.92 \mathrm{~Hz}, 1 \mathrm{H})$, $4.36(\mathrm{t}, J=4.07 \mathrm{~Hz}, 1 \mathrm{H}), 4.16-4.23(\mathrm{~m}, 1 \mathrm{H}), 3.87(\mathrm{t}, J=9.16 \mathrm{~Hz}, 1 \mathrm{H}), 3.70-3.79(\mathrm{~m}, 1 \mathrm{H}), 3.39(\mathrm{~s}, 1 \mathrm{H})$, 
2.54-2.67 (m, 1H), 2.32-2.45 (m, 1H), 2.08-2.23 (m, 1H), 1.88-2.04 (m, 6H), 1.73-1.87 (m, 1H). LCMS calculated for $\mathrm{C}_{21} \mathrm{H}_{26} \mathrm{~F}_{3} \mathrm{~N}_{6} \mathrm{O}_{2}[\mathrm{M}+\mathrm{H}]^{+}: \mathrm{m} / \mathrm{z}=451.20$; found: 451. HPLC: $t_{\mathrm{R}}=1.42 \min ($ Method D).

\section{Synthesis of N-((1R,2S,5R)-5-(tert-butylamino)-2-((S)-2-0xo-3-((6-(trifluoromethyl)quinazolin-4-}

yl)amino)pyrrolidin-1-yl)cyclohexyl)acetamide (2d, Table S1). To a solution of (4R)-9a (30 g, 97 mmol) in IPA $(400 \mathrm{~mL})$ was added TEA $(27 \mathrm{~mL}, 195 \mathrm{mmol})$ and 4-chloro-6-(trifluoromethyl)quinazoline $(25 \mathrm{~g}$, $107 \mathrm{mmol}$ ). The mixture was stirred at $\mathrm{rt}$ overnight and then stirred at $70{ }^{\circ} \mathrm{C}$ for $1 \mathrm{~h}$. The resulted solution was concentrated under reduced pressure to dryness. The residue was dissolved in dichloromethane $(1 \mathrm{~L})$ and extracted with acetic acid (solution I: prepared by combining $700 \mathrm{~mL}$ of water and $22.6 \mathrm{~mL}$ of glacial acetic acid) twice (500 and $200 \mathrm{~mL}$ ). The acidic aqueous layer ( $\mathrm{pH} 4-5)$ was extracted with dichloromethane $(2 \times 300 \mathrm{~mL})$. The dichloromethane layer was extracted with acetic acid (solution II $300 \mathrm{~mL}$ : prepared by combining $300 \mathrm{~mL}$ water with $4 \mathrm{~mL}$ of glacial acetic acid). The combined acetic acid layers were basified with $1 \mathrm{M} \mathrm{NaOH}$ to $\mathrm{pH}>12$ and extracted with dichloromethane $(3 \times 700 \mathrm{~mL})$. The combined organic layers were dried and concentrated to give the crude title compound $\mathbf{2 d}$ as a solid ( $45.6 \mathrm{~g}, 93 \%$ yield). The crude product was purified by recrystallization from EtOAc $(400 \mathrm{~mL}) / \mathrm{Hexane}(900 \mathrm{~mL})$ to give $42.86 \mathrm{~g}(88 \%)$ of 2d with 99.7\% purity. ${ }^{1} \mathrm{H}-\mathrm{NMR}\left(500 \mathrm{MHz}, \mathrm{DMSO}-\mathrm{d}_{6}\right) \delta \mathrm{ppm} 9.71(\mathrm{br}, \mathrm{s}, 1 \mathrm{H}), 9.02(\mathrm{~s}, 1 \mathrm{H}), 8.71(\mathrm{~d}, J=7.97$ $\mathrm{Hz}, 1 \mathrm{H}), 8.59$ (s, 1H), $8.04(\mathrm{dd}, J=8.66,1.79 \mathrm{~Hz}, 1 \mathrm{H}), 7.88(\mathrm{~d}, J=8.52 \mathrm{~Hz}, 1 \mathrm{H}), 5.95(\mathrm{~s}, 1 \mathrm{H}), 4.91-5.13$ $(\mathrm{m}, 1 \mathrm{H}), 4.30-4.57(\mathrm{~m}, 1 \mathrm{H}), 3.86(\mathrm{dt}, J=11.89,3.71,3.64 \mathrm{~Hz}, 1 \mathrm{H}), 3.43-3.57(\mathrm{~m}, 1 \mathrm{H}), 3.35-3.45(\mathrm{~m}, 1 \mathrm{H})$ $3.04(\mathrm{t}, J=3.85 \mathrm{~Hz}, 1 \mathrm{H}), 2.23-2.40(\mathrm{~m}, 1 \mathrm{H}), 2.05-2.22(\mathrm{~m}, 1 \mathrm{H}), 1.90-1.98(\mathrm{~m}, 1 \mathrm{H}), 1.86-1.93(\mathrm{~m}, 3 \mathrm{H})$, 1.50-1.78 (m, 5H), 0.98-1.15 (m, 9H). ${ }^{13} \mathrm{C}-\mathrm{NMR}\left(126 \mathrm{MHz}, \mathrm{DMSO}-\mathrm{d}_{6}\right) \delta \mathrm{ppm} 171.23,169.35,159.54$, 156.87, 151.17, 128.97, 128.20, 125.76 (q, $J=30.52 \mathrm{~Hz}, 1 \mathrm{c}), 121.55$ (br, s, 1c), 124.04 (q, $J=272.11 \mathrm{~Hz}$ 1c), $114.31,53.26,52.39,50.81,47.56,45.70,42.77,34.52,32.17,29.14$ (s, 3c), 26.49, 23.29, 20.30. ${ }^{19} \mathrm{~F}-$ NMR (471 MHz, DMSO-d ${ }_{6}$ ) $\delta$ ppm - 60.34 (s). LCMS calculated for $\mathrm{C}_{25} \mathrm{H}_{34} \mathrm{~F}_{3} \mathrm{~N}_{6} \mathrm{O}_{2}[\mathrm{M}+\mathrm{H}]^{+}: \mathrm{m} / \mathrm{z}=507.26$; ESI-MS: $m / z$ 507.26 ([M+ $\left.\left.\mathrm{H}^{+}\right]\right)$. Anal. Calcd for $\mathrm{C}_{25} \mathrm{H}_{33} \mathrm{~N}_{6} \mathrm{O}_{2} \mathrm{~F}_{3}: \mathrm{C}, 59.27 ; \mathrm{H}, 6.56 ; \mathrm{N}, 16.59 ; \mathrm{F}, 11.25$ Found: C, 59.44; H, 6.64; N, 16.74; F, 10.99. During the workup, the crude product-derived from entry 3 Table 5 was treated with an equal amount of $\mathrm{CH}_{2} \mathrm{Cl}_{2}$ and $2 \%$ aqueous $\mathrm{NH}_{4} \mathrm{Cl}$ followed by the HPLC analyses as shown in Figure S2. We found that the isomer (4R)-9b was exclusively in the organic layer, and left the 
diastereomer (4S)-9b in the aqueous solution (Figure S2). Amazingly, all the undesired isomers were completely removed from the organic solution through a single aqueous workup, which resulted in $>98 \%$ diastereomeric excess of (4R)-9b without any column chromatography purification. Based on the information obtained from single crystal X-ray structures of 1a and our discussion about the subject of "a conformational-switching mechanism to modulate exposed polarity", ${ }_{1}^{1}$ we speculate that the mechanistic rationale behind this observation could be explained by the conformations depicted in Figure S3.

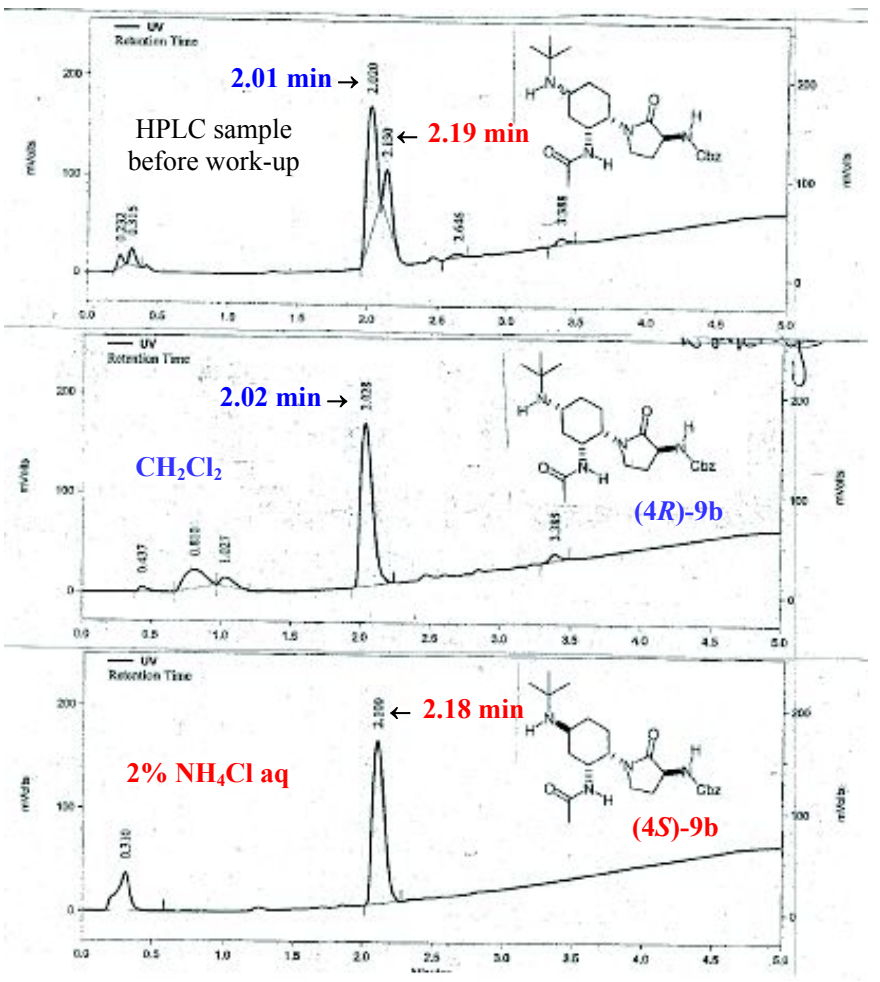

Figure S2. Top panel: HPLC analysis of the crude product as a mixture of diastereoisomers. Middle panel: HPLC analysis indicates only the $R$-isomer in the organic layer. Button panel: HPLC analysis indicates only the $S$-isomer in the aqueous layer.

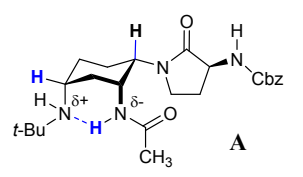

Under mild acidic conditions, the depicted hydrogen bond predominates the intramolecular interactions. Therefore, (4R)-9b existes as 2,4-diaxial conformation (less polar) and distributes into the organic layer. vs.

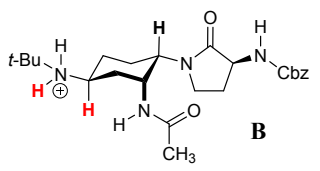

Since the amine in (4S)-9b cannot form an intramolecular hydrogen bond, the protonated conformation is predominant. Therefore,

(4S)-9b existes as 1,4-diequatorial conformation (charged \& polar) and distributes in the aqueous layer.

Figure S3. Conformational-Switching Mechanism-based aqueous workup. 


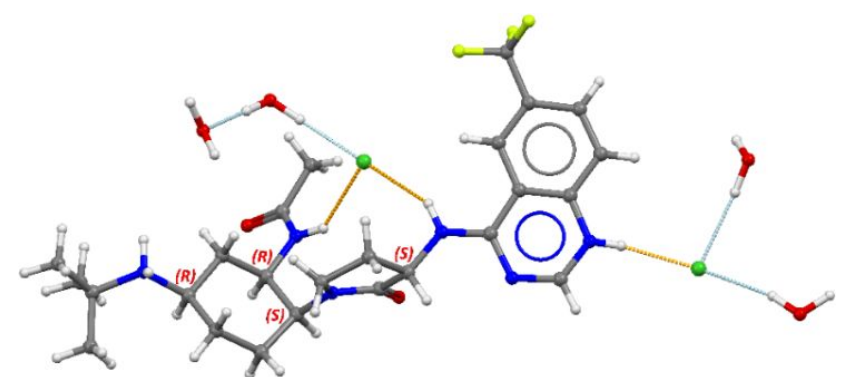

Figure S4. Single X-ray crystal structure of 2d. The structure has been deposited into the Cambridge Crystallographic Data Centre Crystal Structure Database (CCDC-CSD) and Accession Code as CCDC 2055911.

\section{Synthesis of N-((1R,2S,5R)-5-(tert-butylamino)-2-((S)-2-oxo-3-((6-(trifluoromethoxy)quinazolin-4-} yl)amino)pyrrolidin-1-yl)cyclohexyl)acetamide (3, Table S1). To a solution of (4R)-9a (100 mg, 0.322 mmol) in $i$-PrOH $(3221 \mu \mathrm{L})$ was added 4-chloro-6-(trifluoromethoxy)quinazoline (96 mg, $0.387 \mathrm{mmol})$ followed by triethylamine $(65.2 \mathrm{mg}, 0.644 \mathrm{mmol})$. The reaction mixture was stirred at $\mathrm{rt}$ for $4 \mathrm{~h}$. At this time, LCMS showed complete reaction, and the solution was concentrated and purified via column chromatography (30-100\% EtoAc/Hexanes, then 3-7\% MeOH/DCM) to provide the title compound 3 (68 $\mathrm{mg}, 40.4 \%$ yield) as a white solid. ${ }^{1} \mathrm{H}$ NMR $\left(500 \mathrm{MHz}\right.$, METHANOL-D $\left.{ }_{3}\right) \delta \mathrm{ppm} 8.56-8.49(\mathrm{~m}, 1 \mathrm{H}), 8.33$ $(\mathrm{d}, J=1.6 \mathrm{~Hz}, 1 \mathrm{H}), 7.87-7.81(\mathrm{~m}, 1 \mathrm{H}), 7.75(\mathrm{dd}, J=9.3,2.2 \mathrm{~Hz}, 1 \mathrm{H}), 5.25(\mathrm{t}, J=8.2 \mathrm{~Hz}, 1 \mathrm{H}), 4.55(\mathrm{br} \mathrm{d}, J$ $=3.3 \mathrm{~Hz}, 1 \mathrm{H}), 4.01(\mathrm{dt}, J=11.8,3.7 \mathrm{~Hz}, 1 \mathrm{H}), 3.65-3.53(\mathrm{~m}, 2 \mathrm{H}), 3.20($ br s, $1 \mathrm{H}), 2.59-2.48(\mathrm{~m}, 1 \mathrm{H}), 2.24$ (tt, $J=12.4,8.2 \mathrm{~Hz}, 1 \mathrm{H}), 2.00(\mathrm{~s}, 3 \mathrm{H}), 1.99-1.94(\mathrm{~m}, 1 \mathrm{H}), 1.90-1.81(\mathrm{~m}, 3 \mathrm{H}), 1.77-1.67(\mathrm{~m}, 2 \mathrm{H}), 1.17(\mathrm{~s}$, $10 \mathrm{H}$ ). LCMS calculated for $\mathrm{C}_{25} \mathrm{H}_{34} \mathrm{~F}_{3} \mathrm{~N}_{6} \mathrm{O}_{3}[\mathrm{M}+\mathrm{H}]^{+}: \mathrm{m} / \mathrm{z}=523.26$; found: 523. HPLC: $t_{\mathrm{R}}=7.16$ min (Method A).

\section{Synthesis of $N-((S)-1-((1 S, 2 R, 4 R)-2$-acetamido-4-(tert-butylamino)cyclohexyl)-2-oxopyrrolidin-3-yl)-} 6-(tert-butyl)picolinamide (4, Table S1). To a solution of (4R)-9a (43 $\mathrm{mg}, 0.139 \mathrm{mmol})$ in acetonitrile (1.5 $\mathrm{mL}$ ) was added 3-(trifluoromethyl)benzoic acid (29.0 mg, $0.152 \mathrm{mmol})$, HOBt (25.5 mg, $0.166 \mathrm{mmol})$, diisopropylethylamine $(0.058 \mathrm{~mL}, 0.332 \mathrm{mmol})$ and EDC $(34.5 \mathrm{mg}, 0.180 \mathrm{mmol})$. The reaction mixture was stirred at $\mathrm{rt}$ for $6 \mathrm{~h}$. The reaction was diluted with methanol and purified in 2 injections by preparative HPLC (Waters Sunfire C18 $19 \times 100 \mathrm{~mm}, 10-90 \%$ methanol-water containing 0.1\% trifluoroacetic acid, $10 \mathrm{~min}, 20$ $\mathrm{mL} / \mathrm{min}, 220 \mathrm{nM}$ ). Fractions 5 and 6 from run 1 and fractions 21 and 22 from run 2 were combined and concentrated under vacuum. The residue was lyophilized from water and a small amount of acetonitrile to 
give the title compound 4 (61.9 mg, 75\% yield). ${ }^{1} \mathrm{H}$ NMR (400 MHz, METHANOL-d 4 ) $\delta \mathrm{ppm} 8.19(\mathrm{~s}, 1 \mathrm{H})$, $8.13(\mathrm{~d}, J=7.9 \mathrm{~Hz}, 1 \mathrm{H}), 7.88(\mathrm{~d}, J=7.7 \mathrm{~Hz}, 1 \mathrm{H}), 7.71(\mathrm{t}, J=7.7 \mathrm{~Hz}, 1 \mathrm{H}), 4.43-4.47(\mathrm{~m}, 1 \mathrm{H}), 4.18-4.29(\mathrm{~m}$, 2H), $3.90(\mathrm{td}, J=9.3,2.5 \mathrm{~Hz}, 1 \mathrm{H}), 3.77(\mathrm{q}, J=8.1 \mathrm{~Hz}, 1 \mathrm{H}), 3.62(\mathrm{tt}, J=12.1,3.9 \mathrm{~Hz}, 1 \mathrm{H}), 2.49-2.59(\mathrm{~m}$, 1H), 2.30-2.40 (m, 1H), $2.25(\mathrm{~d}, J=12.5 \mathrm{~Hz}, 1 \mathrm{H}), 2.06-2.15(\mathrm{~m}, 3 \mathrm{H}), 1.96(\mathrm{~s}, 3 \mathrm{H}), 1.76-1.92(\mathrm{~m}, 3 \mathrm{H}), 1.45$ (s, 9H). LCMS calculated for $\mathrm{C}_{24} \mathrm{H}_{34} \mathrm{~F}_{3} \mathrm{~N}_{4} \mathrm{O}_{3}[\mathrm{M}+\mathrm{H}]^{+}: \mathrm{m} / \mathrm{z}=483.25$; found: 483 . HPLC: $t_{\mathrm{R}}=4.8 \mathrm{~min}$ (Method C).

\section{Synthesis of $N$-((S)-1-((1S,2R,4R)-2-acetamido-4-(methylamino)cyclohexyl)-2-oxopyrrolidin-3-yl)-6-} (tert-butyl)picolinamide (5a, Table S1). To a solution of 16 (14 mg, $0.052 \mathrm{mmol})$ in $2 \mathrm{ml}$ of DMF was added 6-tert-butylpicolinic acid, $\mathrm{HCl}(11.25 \mathrm{mg}, 0.052 \mathrm{mmol}), \mathrm{BOP}(27.7 \mathrm{mg}, 0.063 \mathrm{mmol})$ and TEA (0.036 $\mathrm{ml}, 0.261 \mathrm{mmol})$. The mixture was stirred at $\mathrm{rt}$ for $1 \mathrm{~h}$. The residue was dissolved in $50 \mathrm{~mL}$ of DCM and washed with saturated $\mathrm{NaHCO}_{3}$ solution $(20 \mathrm{~mL})$, dried over anhydrous $\mathrm{Na}_{2} \mathrm{SO}_{4}$ and concentrated under reduced pressure to give the crude product which was purified with prep HPLC. The title compound 5a was obtained as TFA salt (15 mg, $0.028 \mathrm{mmol}, 52.9 \%$ yield). ${ }^{1} \mathrm{H}$ NMR (400 MHz, METHANOL-d $\left.{ }_{4}\right) \delta \mathrm{ppm} 7.91$ (s, 2H), $7.82(\mathrm{~s}, 1 \mathrm{H}), 4.96(\mathrm{~m}, 1 \mathrm{H}), 4.52(\mathrm{~m}, 1 \mathrm{H}), 4.45(\mathrm{~m}, 1 \mathrm{H}), 4.28(\mathrm{~m}, 1 \mathrm{H}), 3.95(\mathrm{~m}, 2 \mathrm{H}), 3.86(\mathrm{~m}, 1 \mathrm{H})$, $2.80(\mathrm{~s}, 3 \mathrm{H}), 2.64(\mathrm{~m}, 2 \mathrm{H}), 2.46(\mathrm{~m}, 2 \mathrm{H}), 2.21(\mathrm{~m}, 2 \mathrm{H}), 2.00(\mathrm{~s}, 3 \mathrm{H}), 1.47(\mathrm{~s}, 9 \mathrm{H})$. LCMS calculated for $\mathrm{C}_{23} \mathrm{H}_{36} \mathrm{~N}_{5} \mathrm{O}_{3}[\mathrm{M}+\mathrm{H}]^{+}: \mathrm{m} / \mathrm{z}=430.28$; found: 430. HPLC: $t_{\mathrm{R}}=2.10 \min ($ Method $\mathrm{E}$ ).

\section{Synthesis of $N$-((S)-1-((1S,2R,4R)-2-acetamido-4-(tert-butylamino)cyclohexyl)-2-oxopyrrolidin-3-yl)-}

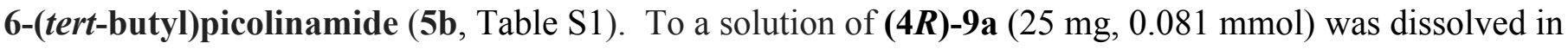
DMF (1.5 mL) prior to the addition of 6-(tert-butyl)picolinic acid (18.76 mg, $0.105 \mathrm{mmol}), \mathrm{HOBt}$ (16.03 mg, $0.105 \mathrm{mmol})$, EDC (20.07 mg, $0.105 \mathrm{mmol})$, and 4-methylmorpholine (0.035 mL, $0.322 \mathrm{mmol})$. This was stirred overnight before EtOAc was added along with brine. The organic layer was washed with brine, $1 \mathrm{~N}$ $\mathrm{HCl}$, and sat $\mathrm{NaHCO}_{3}$ before it was dried over $\mathrm{MgSO}_{4}$, filtered, and concentrated. The resulting residue was purified by preparative reverse-phase HPLC (Luna $30 \times 100 \mathrm{~mm}, 20 \%$ B to $100 \%$ B over 10 min $\mathrm{MeCN} / \mathrm{H} 2 \mathrm{O} / 0.1 \%$ TFA, $100 \% \mathrm{~B} 10 \mathrm{~min}$ to $15 \mathrm{~min}, 30 \mathrm{~mL} / \mathrm{min}, 220$ wavelength, product retention $=7.8$ $\min )$ to give the title compound $\mathbf{5 b}\left(9.7 \mathrm{mg}, 0.021 \mathrm{mmol}, 25.5 \%\right.$ yield). ${ }^{1} \mathrm{H}$ NMR (400 MHz, METHANOL$\left.\mathrm{d}_{4}\right) \delta \mathrm{ppm} 7.94-7.82(\mathrm{~m}, 2 \mathrm{H}), 7.69-7.62(\mathrm{~m}, 1 \mathrm{H}), 4.50-4.44(\mathrm{~m}, 1 \mathrm{H}), 4.41-4.33(\mathrm{~m}, 1 \mathrm{H}), 4.24(\mathrm{dt}, J=12.9$, 
$4.6 \mathrm{~Hz}, 1 \mathrm{H}), 3.91(\mathrm{td}, J=9.3,2.8 \mathrm{~Hz}, 1 \mathrm{H}), 3.78(\mathrm{q}, J=8.3 \mathrm{~Hz}, 1 \mathrm{H}), 3.67-3.57(\mathrm{~m}, 1 \mathrm{H}), 2.66-2.54(\mathrm{~m}, 1 \mathrm{H})$, 2.40-2.30 (m, 1H), $2.25(\mathrm{~d}, J=12.3 \mathrm{~Hz}, 1 \mathrm{H}), 2.16-2.06(\mathrm{~m}, 3 \mathrm{H}), 1.98(\mathrm{~s}, 3 \mathrm{H}), 2.0-1.77(\mathrm{~m}, 3 \mathrm{H}), 1.45(\mathrm{~s}$, 9H), $1.42(\mathrm{~s}, 9 \mathrm{H})$. LCMS calculated for $\mathrm{C}_{26} \mathrm{H}_{42} \mathrm{~N}_{5} \mathrm{O}_{3}[\mathrm{M}+\mathrm{H}]^{+}: \mathrm{m} / \mathrm{z}=472.32$; found: 472. HPLC: $t_{\mathrm{R}}=6.3$ $\min ($ Method B).

\section{Synthesis of $\quad N-((1 R, 2 S, 5 R)-2-((S)-3-((6-(t e r t-b u t y l) p y r i d o[3,2-d] p y r i m i d i n-4-y l) a m i n o)-2-$} oxopyrrolidin-1-yl)-5-(tert-butylamino)cyclohexyl)acetamide (6, Table S1). Step-1: a suspension of 6tert-butylpyrido[3,2-d]pyrimidin-4-ol $(200 \mathrm{mg}, 0.984 \mathrm{mmol})$ in $\mathrm{POCl}_{3}(10 \mathrm{~mL})$ was heated to reflux (oil bath $120{ }^{\circ} \mathrm{C}$ ) under nitrogen atmosphere. After 30 minutes at reflux, a yellow homogeneous solution was observed, and the reaction was allowed to reflux for an additional 60 minutes. The mixture was concentrated in vacuo, then stripped 4 times from $20 \mathrm{~mL}$ methylene chloride to remove the $\mathrm{POCl}_{3}$ residual. The residue was suspended in methylene chloride $(20 \mathrm{~mL})$, and saturated sodium carbonate $(5 \mathrm{~mL})$ was added slowly and carefully. The biphasic solution was shaked until gas evolution had ceased, and the $\mathrm{pH}$ of the aqueous phase was no longer acidic $(\mathrm{pH} \sim 11)$. The layers were separated. The aqueous phases were extracted again with $\mathrm{CH}_{2} \mathrm{Cl}_{2}$, and the combined organic phases were washed with sat. $\mathrm{NaHCO}_{3}$, brine, dried over sodium sulfate, filtered, and concentrated on a rotavapor. This crude solution was purified over a silica gel column to yield 6-tert-butyl-4-chloropyrido[3,2-d]pyrimidine (100 $\mathrm{mg}, 0.451 \mathrm{mmol}, 45.8 \%$ yield) as a pale yellow powder used for the next step. ${ }^{1} \mathrm{H}$ NMR (400 MHz, CHLOROFORM-d) $\delta$ ppm $8.98(\mathrm{~m}, 1 \mathrm{H}), 8.21(\mathrm{~d}, J=$ $8.8 \mathrm{~Hz}, 1 \mathrm{H}), 7.83(\mathrm{~d}, J=8.8 \mathrm{~Hz}, 1 \mathrm{H}), 1.43(\mathrm{~s}, 9 \mathrm{H})$. LCMS calculated for $\mathrm{C}_{11} \mathrm{H}_{13} \mathrm{~N}_{3} \mathrm{Cl}[\mathrm{M}+\mathrm{H}]^{+}: \mathrm{m} / \mathrm{z}=222.07$; Found ESI-MS: $m / z 222.2\left(\left[\mathrm{M}+\mathrm{H}^{+}\right]\right)$. Step-2: to a solution of $\mathbf{( 4 R ) - 9 a}(60 \mathrm{mg}, 0.193 \mathbf{m m o l})$ in acetonitrile $(3 \mathrm{~mL})$ was added $\mathrm{Et}_{3} \mathrm{~N}(0.135 \mathrm{~mL}, 0.966 \mathrm{mmol})$, following by addition of 6-tert-butyl-4-chloropyrido[3,2d]pyrimidine (51.4 mg, $0.232 \mathrm{mmol}$ ) at $\mathrm{rt}$. The reaction was stirred at $\mathrm{rt}$. under $\mathrm{N}_{2}$ for overnight. The crude product was purified by Prep HPLC (Waters XBRIDGE C18 19 X 100 mm, 15-100\% B, 12 Mins) to give the title compound 6 (53 mg as free amine) in 55\% yield. ${ }^{1} \mathrm{H}$ NMR (400 MHz, METHANOL- $\left.\mathrm{d}_{4}\right) \delta \mathrm{ppm} 8.49$ $(\mathrm{s}, 1 \mathrm{H}), 8.07-8.03(\mathrm{~m}, 1 \mathrm{H}), 8.02-7.98(\mathrm{~m}, 1 \mathrm{H}), 4.93-4.86(\mathrm{~m}, 1 \mathrm{H}), 4.34(\mathrm{~d}, J=4.2 \mathrm{~Hz}, 1 \mathrm{H}), 4.23(\mathrm{dt}, J=$ 12.9, 4.7 Hz, 1H), 3.94-3.85 (m, 1H), 3.81-3.71 (m, 1H), 3.69-3.58 (m, 1H), 2.76-2.64 (m, 1H), 2.48-2.34 
(m, 1H), $2.20(\mathrm{~d}, J=13.0 \mathrm{~Hz}, 2 \mathrm{H}), 2.13-1.92(\mathrm{~m}, 4 \mathrm{H}), 1.89(\mathrm{~s}, 3 \mathrm{H}), 1.47(\mathrm{~s}, 9 \mathrm{H}), 1.45(\mathrm{~s}, 9 \mathrm{H})$. LCMS calculated for $\mathrm{C}_{27} \mathrm{H}_{42} \mathrm{~N}_{7} \mathrm{O}_{2}[\mathrm{M}+\mathrm{H}]^{+}: \mathrm{m} / \mathrm{z}=496.34$; found: 496. HPLC: $t_{\mathrm{R}}=4.5 \min$ (Method B).

Biological Methods. All procedures involving animals were reviewed and approved by the Institutional Animal Care and Use Committee and conformed to the "Guide for the Care and Use of Laboratory Animals" published by the National Institutes of Health (NIH Publication no. 85-23, revised 2011). Detailed biological experimental procedures and assay conditions used in this study can be found in our publication: Modulators of chemokine receptor activity, crystalline forms and process. ${ }^{2}$

Single-Crystal X-ray Structure Determination of 2d. Crystals of $2 d$ grew as colorless plates from an acetonitrile/hexane solution kept at $5{ }^{\circ} \mathrm{C}$ for $\sim 48$ hours. Single crystal X-ray diffraction data were collected on a Bruker-AXS X8-Proteum Kappa goniometer and APEXII detector. Intensities were measured using $\mathrm{Cu}$ K $\alpha$ radiation $(\lambda=1.5418 \AA)$ with the crystal kept at a constant temperature using an Oxford cryosystem during data collection. Indexing and processing of the measured intensity data were carried out with Bruker's SAINT-APEX2 program suite. The crystal structure was solved using SHELXS-97 and the atomic coordinates were refined using SHELX-2014/6. Difference maps were examined at all stages of refinement. All hydrogen atoms, except those on lattice water molecules were calculated from an idealized geometry with standard bond lengths and angles and refined using a riding model. Hydrogen atoms on lattice water molecules were located from residual electron density maps and allowed to refine with distance restraints.

The crystalline structure is hydrated and belongs to the orthorhombic $P 222_{1}$ space group with a single BMS-753426 conformer in the asymmetric unit $\left(Z^{\prime}=1\right)$. Compound $\mathbf{2 d}$ is protonated at the $t$-butyl-amine function and the N1 position of the quinazoline ring, with the charge balanced by two symmetry independent $\mathrm{Cl}^{-}$anions. In addition there are 3.5 molecules of water in the asymmetric unit; one water is positioned directly on a crystallographic 2-fold symmetry element. The noted absolute configuration was established through analysis of the anomalous dispersion signal using the Flack method; ${ }^{3}$ the Flack parameter (x) was found to be $0.044(8)$. 
Table S2. Crystal data and structure refinement for $\mathbf{2 d}$.

Identification code

$2 d$

Empirical formula

$\mathrm{C}_{25} \mathrm{H}_{42} \mathrm{~N}_{6} \mathrm{O}_{5.5} \mathrm{~F}_{3} \mathrm{Cl}_{2}$

Formula weight

642.54

Temperature/K

203

Crystal system

orthorhombic

Space group

P222 1

$\mathrm{a} / \AA$

7.0496(5)

$\mathrm{b} / \AA$

15.3811(11)

$\mathrm{c} / \AA$

28.286(2)

$\alpha{ }^{\circ}$

90

$\beta /{ }^{\circ}$

90

$\gamma /{ }^{\circ}$

90

Volume $/ \AA^{3}$

3067.1(4)

Z

4

$\rho_{\text {calc }} \mathrm{g} / \mathrm{cm}^{3}$

1.392

$\mu / \mathrm{mm}^{-1}$

2.473

$\mathrm{F}(000)$

1356.0

Crystal size $/ \mathrm{mm}^{3}$

$0.15 \times 0.08 \times 0.015$

Radiation

$\mathrm{CuK} \alpha(\lambda=1.54178)$

$2 \Theta$ range for data collection/ ${ }^{\circ} 5.746$ to 110.138

Index ranges

$-7 \leq \mathrm{h} \leq 7,-16 \leq \mathrm{k} \leq 16,-29 \leq 1 \leq 15$

Reflections collected

11448

Independent reflections

$3679\left[\mathrm{R}_{\text {int }}=0.0365, \mathrm{R}_{\text {sigma }}=0.0366\right]$

Data/restraints/parameters

$3679 / 8 / 407$

Goodness-of-fit on $\mathrm{F}^{2}$

1.090

Final $R$ indexes $[\mathrm{I}>=2 \sigma(\mathrm{I})] \quad \mathrm{R}_{1}=0.0536, \mathrm{wR}_{2}=0.1444$

Final $\mathrm{R}$ indexes [all data] $\quad \mathrm{R}_{1}=0.0565, \mathrm{wR}_{2}=0.1469$

Largest diff. peak/hole / e $\AA^{-3} 0.44 /-0.27$

Flack parameter

$0.044(8)$

\section{References:}

1. Yang, M. G.; Xiao, Z.; Cherney, R. J.; Tebben, A. J,; Batt, D. G.; Brown, G. D.; Chen, J.; Cvijic, M. E.; Dabros, M.; Duncia, J. V.; Galella, M. A.; Gardner, D. S.; Khandelwal, P.; Ko, S. S.; Malley, M. F.; Mo, R.; Pang, J.; Rose, A. V.; Santella, J. B.; Shi, H.; Srivastava, A.; Traeger, S. C.; Wang, B.; Xu, S.; Zhao, R.; Barrish, J. C.; Mandlekar, S.; Zhao, Q.; Carter, P. H. Use of a conformational-switching mechanism to modulate exposed polarity: discovery of CCR2 antagonist BMS-741672. ACS Med. Chem. Lett. 2019, 10 (3), $300-305$.

2. Yang, M. G.; Cherney, R. J. Modulators of chemokine receptor activity, crystalline forms and process. US patent 2010, US 7,671,062 B2.

3. Parsons, S.; Flack, H. D.; Wagner, T. Use of intensity quotients and differences in absolute structure refinement. Acta Cryst. 2013, B69, 249-259. 